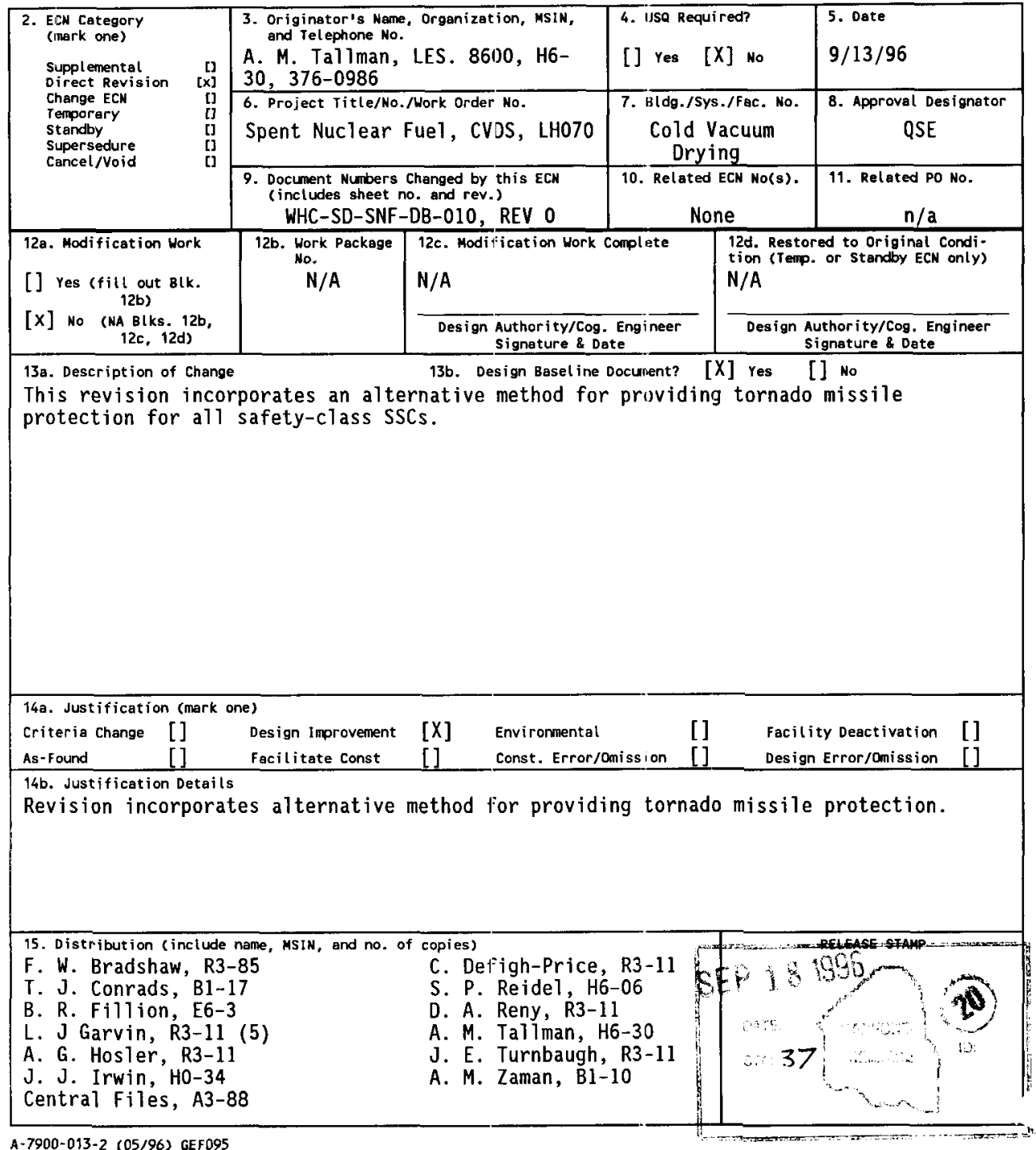




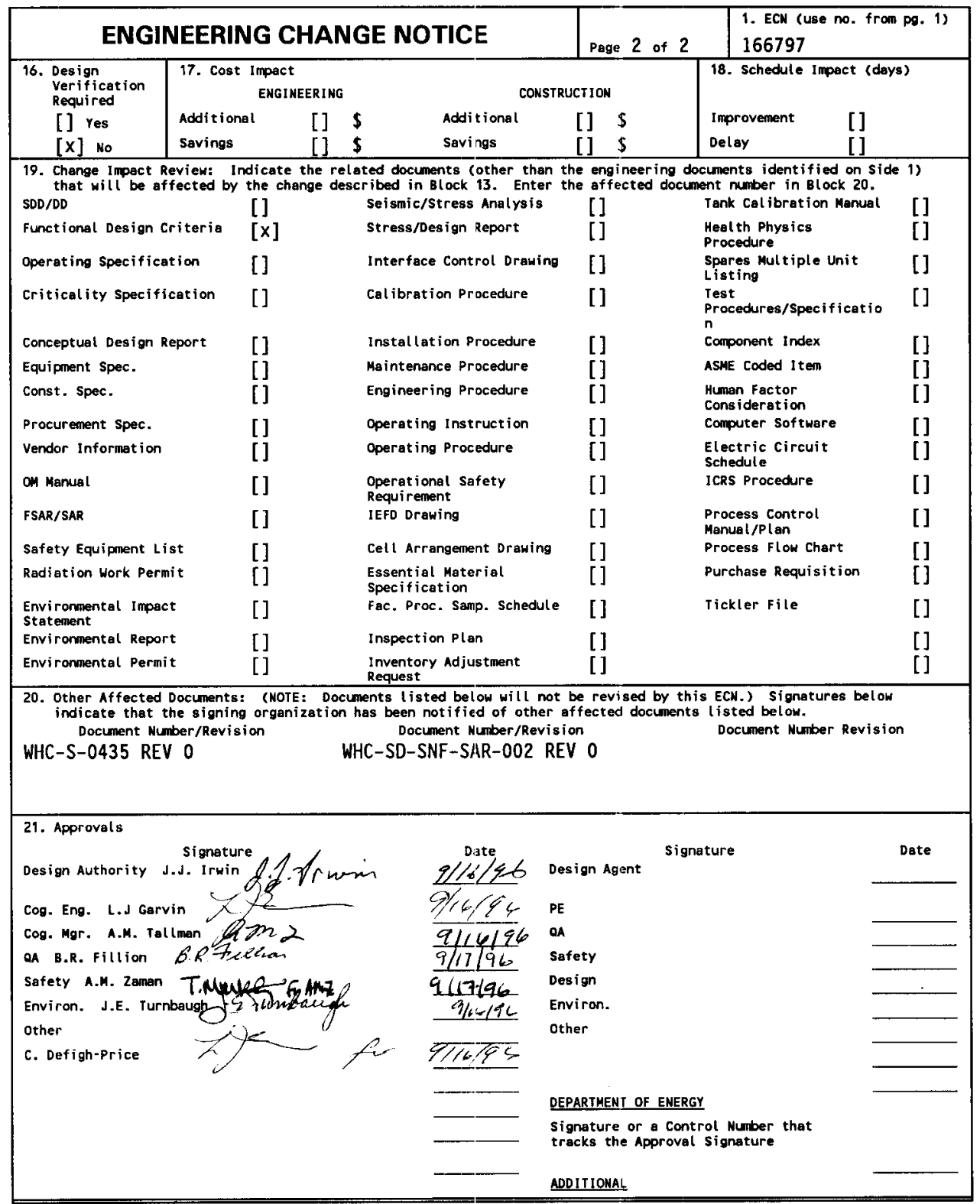




\section{Cold Vacuum Drying System Natural Phenomena Hazards}

Ann M. Tallman

Westinghouse Hanford Company, Richland, WA 99352

U.S. Department of Energy Contract DE-ACO6-87RL10930

$\begin{array}{lll}\text { EDT/ECN: } & 156797 & \text { UC: } 2000 \\ \text { Org Code: } & 86000 & \text { Charge Code: } \\ \text { B\&R Code: } & \text { EW3135070 } & \text { Total Pages: } 44\end{array}$

Key Words: Natural phenomena hazards, design loads, seismic, flood, ashfal1, wind, tornado, lightning.

Abstract: This document specifies the natural phenomena design loads for the Cold Vacuum Drying System.

TRADEMARK DISCLAIMER. Reference herein to any specific commercial product, process, or service by trade name, trademark, manufacturer, or otherwise, does not necessarily constitute or imply its endorsement, recomendation, or favoring by the United states Government or any agency thereof or its contractors or subcontractors.

Printed in the United States of America. To obtain copies of this document, contact: WHC/BCS Document Control Services, P.O. BOX 1970, Maitstop H6-08, Richland WA 99352, Phone (509) 372-2420; Fax (509) 376-4989.
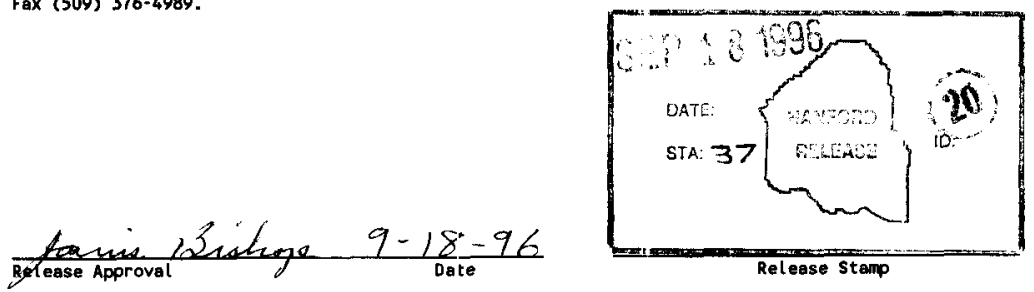

\section{Approved for Public Release}


(2) Title

COLD VACUUM DRYING SYSTEM NATURAL PHENOMENA HAZARDS

CHANGE CONTROL RECORD

\begin{tabular}{|c|c|c|c|}
\hline \multirow{2}{*}{ Revision } & \multirow{2}{*}{ (4) Description of Change - Replace, Add, and Delete Pages } & \multicolumn{2}{|c|}{ Authorized for Release } \\
\hline & & (5) Cog. Engr. & (6) Cog. Mgr. \\
\hline 0 & (7) EDT $610756,6 / 7 / 9 \notin$ & AM Tal1man & LJ Garvin \\
\hline $1 \mathrm{RS}$ & $\begin{array}{l}\text { Page } 10 \text {, An alternative method for } \\
\text { providing tornado missile protection has } \\
\text { been added. } E C A-\angle 66 C^{\prime}>\end{array}$ & AM 1 Tallman & Lu Garvin $=$ \\
\hline & & & \\
\hline & & & \\
\hline & & & \\
\hline & & & \\
\hline & & & \\
\hline & & & \\
\hline & & & \\
\hline & & & \\
\hline & & & \\
\hline & & & \\
\hline & & & \\
\hline & & & \\
\hline & & & \\
\hline & & & \\
\hline & & & \\
\hline & & & \\
\hline & & & \\
\hline & & & \\
\hline & & & \\
\hline & & & \\
\hline & & & \\
\hline & & & \\
\hline & & & \\
\hline & & & \\
\hline & & & \\
\hline & & & \\
\hline & & & \\
\hline & & & \\
\hline & & & \\
\hline & & & \\
\hline & & & \\
\hline & & & \\
\hline
\end{tabular}


COLD VACUUM DRYING SYSTEM

NATURAL PHENOMENA HAZARDS

WHC-SD-SNF-DB-010

Revision 1

September 1996 
WHC-SD-SNF-DB-010 REV 1

This page intentionally left blank. 


\section{CONTENTS}

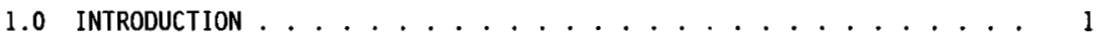

2.0 SEISMIC CRITERIA . . . . . . . . . . . . . . . . 1

2.1 BACKGROUND . . . . . . . . . . . . 1

2.2 U.S. DEPARTMENT OF ENERGY DIESIGN REQUIREMENTS . . . . . . . 4

3.0 WIND AND TORNADO CRITERIA . . . . . . . . . . . . . 4

3.1 BACKGROUND . . . . . . . . . . . . . . 4

3.2 U.S. DEPARTMENT OF ENERGY DIESIGN REQUIREMENTS : . . . . 4

3.3 U.S. NUCLEAR REGULATORY COMIIISSION DESIGN REQUIREMENTS . . . . 8

4.0 VOLCANIC ASH CRITERIA . . . . . . . . . . . . . 12

4.1 BACKGROUND ........................... 12

4.2 U.S. DEPARTMENT OF ENERGY DISSIGN REQUIREMENTS . . . . . 12

4.3 U.S. NUCLEAR REGULATORY COMMISSION DESIGN REQUIREMENTS . . . 16

5.0 FLOOD CRITERIA . . . . . . . . . . . . . . 17

5.1 BACKGROUND . . . . . . . 17

5.2 U.S. DEPARTMENT OF ENERGY DESIGN REQUIREMENTS . . . . . . 17

5.2 .1 Local Runoff. . . . . . . . . . . . 17

5.2 .2 River Flooding. . . . . . . . 17

5.3 U.S. NUCLEAR REGULATORY COMMISSION DESIGN REQUIREMENTS . . . 17

5.3 .1 Local Runoff . . . . . . . . . . . . . 18

5.3 .2 River Flooding ................... 18

6.0 LIGHTNING . . . . . . . . . . . . . . 18

7.0 SNOW LOAD ....................... 20

8.0 REFERENCES ......................... 20

APPENDIXES

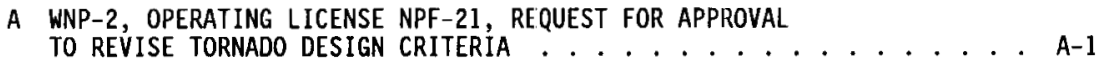

B REVISION OF TORNADO DESIGN CRITERIA, FOR THE WASHINGTON PUBLIC POWER SUPPLY SYSTEM (WPPSS)

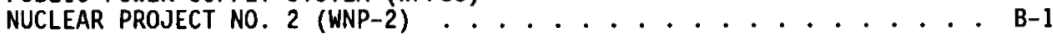




\section{LIST (IF FIGURES}

1 Location of the Cold Vacuum Drying System . . . . . . . . . . . 2

2 Performance Category 3 Horizontal and Vertical Design Response Spectra with 5\% Dainping at the Site of the Cold Vacuum Drying System . . . . . . . . . . . . 5

3 Straight Wind and Tornado Hazards . . . . . . . . . . . . . . . 7

4 Annual Probability of One Centimeter or More of Volcanic Ash Accumulation in Washington and Oregon from Major Cascade Range Volcanoes.................. 13

5 Annual Probability of 10 Centimeters or More of Volcanic Ash Accumulation in Washington and Oregon from Major Cascade Range Volcanoes . . . . . . . . . . . . . . . 14

6 Cascade Range Volcanic Ash Hazard . . . . . . . . . . . . . 15

\section{LIST OF TABLES}

1 Cold Vacuum Drying System Safety-Class Natural Phenomena Design Loads... . . . . . . . . . . . . . . . . 3

2 Cold Vacuum Drying System Design Response Spectra . . . . . . . . . . 6

3 Design Basis Loads for Ashfall Criteria . . . . . . . . . . . . 16

4 Extreme Precipitation Estimates for the Hanford Site . . . . . . . . 19 


\section{WHC-SD-SNF-DB-010 REV 1}

\section{LIST OF TERMS}

$\begin{array}{ll}\text { BP } & \text { before present } \\ \text { CVDS } & \text { Cold Vacuum Drying System } \\ \text { DOE } & \text { U.S. Department of Energy } \\ \text { NPH } & \text { natural phenomena hazard } \\ \text { NRC } & \text { U.S. Nuclear Regulatory Commission } \\ \text { PMP } & \text { probable maximum precipitation } \\ \text { Supp1y System } & \text { Washington Public Power Supply System } \\ \text { WNP-2 } & \text { Washington Public Power Supply System Nuclear Plant } 2\end{array}$




\section{WHC-SD-SNF-DB-010 REV 1}

This page intentionally left blank. 


\section{COLD VACUUN DRYING SYSTEM \\ NATURAL PHENONENA HAZARDS}

\subsection{INTRODUCTION}

This document specifies natural phenomena hazard (NPH) Toads for use in the design and construction of the Cold Vacuum Drying System (CVDS), a facility that will be located in the $100 \mathrm{~K}$ Area of the Hanford Site (Figure 1), U.S. Department of Energy (DOE) requirements governing the derivation and mitigation of NPH 10ads are found in DOE Order 5480.28, Natura7 Phenomena Hazards Mitigation, and its supporting standards: DOE-STD-1020-94, Natural Phenomena Hazards Design and Evaluation Criteria for Department of Energy Facilities; D0E-STD-1022-94, Natural Phenomena Hazards Site Characteristics Criteria; and DOE-STD-1023-95, Natural Phenomena Hazards Assessment Criteria. DOE Order 5480.i8 requires that each structure, system, and component be assigned to one of five performance categories based on safety class and hazard category. Each performance category has an associated NPH goal that serves as a measure of the level of protection required against potential natural phenomena. The CVDS facility has been designated a Performance Category 3 facility (WHC .1996).

DOE regulatory policy for the design and construction of the CVDS requires a level of nuclear safety comparable to that of U.S. Nuclear Regulatory Commission (NRC) licensed facilities (Grumbly 1995). The NRC requirements appropriate for deriving NPH loads for the CVDS are found in Title 10, Code of Federal Regulations, Part 72, "Licensing Requirements for the Independent Storage of Spent Nuclear Fuel and High-Level Radioactive Waste" (10 CFR 72). With the exception of earthquake-induced ground motion, the compliance to both NRC and DOE recluirements is accomplished by using the more stringent of the requirements for the design. The NPH design loads for the CVDS facility are summarized in Table 1 . The remainder of this document provides more detail on NPH loads and reviews the derivation of these loads.

\subsection{SEISIMIC CRITERIA}

\subsection{BACKGROUND}

A comparison of the NRC and DOE seismic design requirements and a discussion of the CVDS facility's seismic design strategy are presented in WHC-SD-SNF-DB-004, Spent Nuclear Fuel Project Seismic Design Criteria, Nuclear Regulatory Commission Equivalency Evaluation Report (WHC 1996), and are not repeated here. The DOE seismic design requirements are being used for the CVDS facility. The seismic characteristics and hazard assessment of the Hanford Site are discussed in WHC-SD-W236A-TI-002, Probabilistic Seismic Hazard Analysis, DOE Hanford Site, Washington (Geomatrix 1996). 


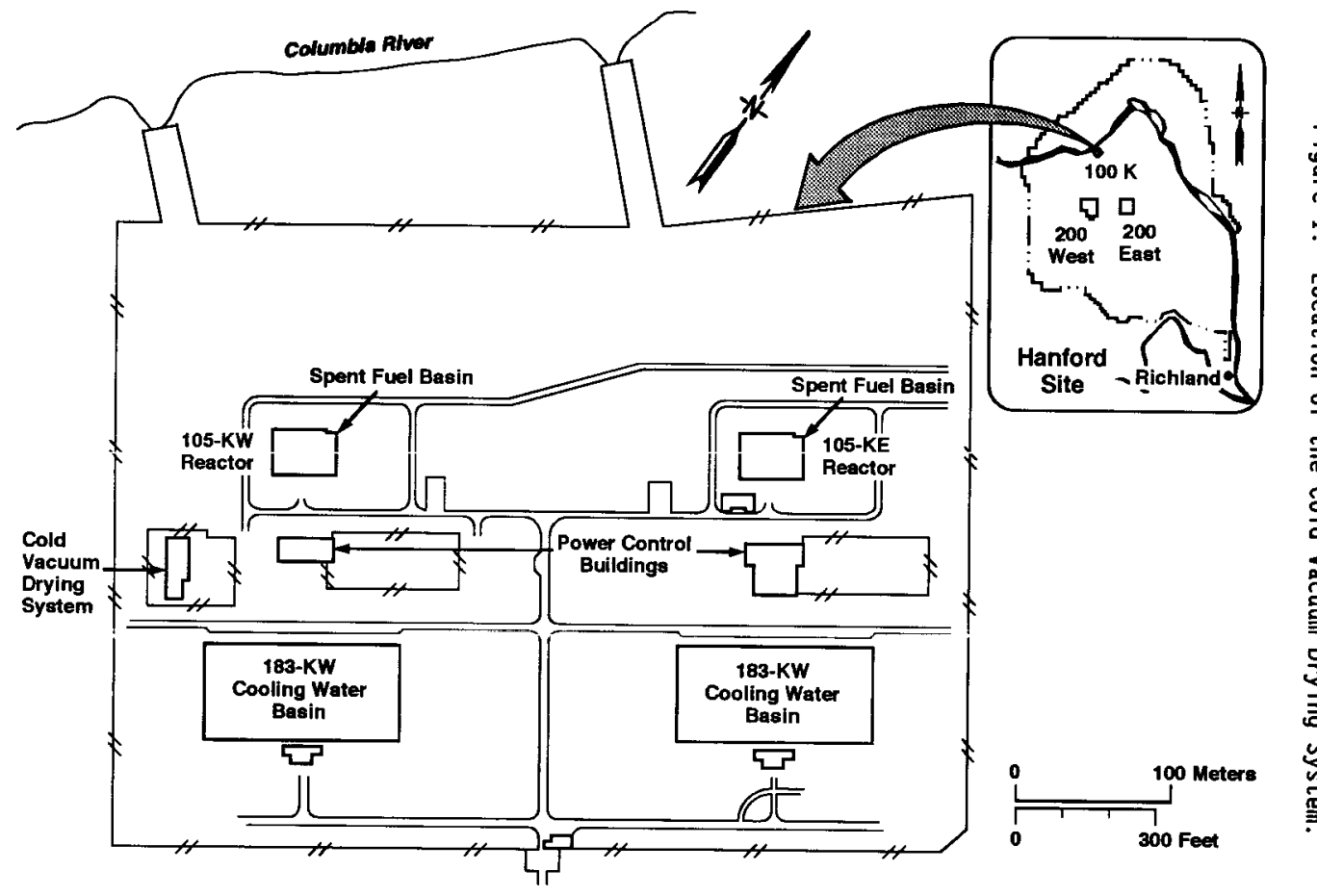

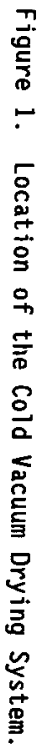

H9502015.6a $425 / 96$ CVDS 
Table 1. Cold Vacuum Drying System Safety-Class Natural Phenomena Design Loads.

\begin{tabular}{|c|c|c|}
\hline Hazard & Load & Appl ication documents \\
\hline Seismic & $0.26 \mathrm{~g}$ equal hazard response spectra" & $\begin{array}{l}\text { DOE Order } 5480.28^{\circ} \\
\text { DOE Standard } 1020-94^{\circ}\end{array}$ \\
\hline Straight wind & $129 \mathrm{~km} / \mathrm{h}(80 \mathrm{mi} / \mathrm{h})$, fastest mile at $9 \mathrm{~m}(30 \mathrm{ft})$ & $\begin{array}{l}\text { ASCE-7-93 } \\
\text { DOE Standard } 1020-94 \text { (including missiles) }\end{array}$ \\
\hline Tornado & $\begin{array}{l}\text { Wind speeds } \\
322 \mathrm{~km} / \mathrm{h}(200 \mathrm{mi} / \mathrm{h}) \text { total } \\
257 \mathrm{~km} / \mathrm{h}(160 \mathrm{mi} / \mathrm{h}) \text { rotational } \\
64 \mathrm{~km} / \mathrm{h}(40 \mathrm{mi} / \mathrm{h}) \text { trans lational }\end{array}$ & $\begin{array}{l}\text { MRC Standard Review Plan" } \\
\text { 3.3.2 Tornado Loading }\end{array}$ \\
\hline Volcanic ash & $117 \mathrm{~kg} / \mathrm{m}^{2}\left(24 \mathrm{lb} / \mathrm{ft}^{2}\right)$ ground ash load & $\begin{array}{l}\text { NRC Standard Review Plan } \\
\text { 3.8.4 Other Seismic Category Structures }\end{array}$ \\
\hline Flooding & $\begin{array}{l}\text { Columbia River: } 140 \mathrm{~m}(460 \mathrm{ft}) \text { above mean } \\
\text { sea level } \\
\text { site drainage basin: } 19 \mathrm{~cm}(7.4 \text { in.) for } \\
\text { 6-hour probable maximm precipitation } \\
\text { site drainage: } 23 \mathrm{~cm}(9.2 \text { in.) for } \\
\text { 6-hour probable maximm precipitation }\end{array}$ & $\begin{array}{l}\text { AHS } 1 / \text { ANS }-2.8-1992^{\circ} \\
\text { MRC Standard Review Plan } \\
2.4 .2 \text { floods }\end{array}$ \\
\hline Lightning & $\begin{array}{l}\text { DOE-RL and RHO, Lightning protection shall be considered for } \\
\text { facility. }\end{array}$ & NFPA $780^{\circ}$ \\
\hline Snow & $98 \mathrm{~kg} / \mathrm{m}^{2}\left(20 \mathrm{lb} / \mathrm{ft}^{2}\right)$ ground load & ASCE- $\boldsymbol{Y}^{\circ}$ \\
\hline
\end{tabular}

Note: Missiles are considered to strike surfaces in any direction, and the vertical velocities are $70 \%$ of the horizontal velocities except for the 1 -in steel rod, wich has the same velocity in any direction. The utility pole and autonobile are considered to strike surfaces up to maximum of $9.1 \mathrm{~m}(30 \mathrm{ft})$ above the highest finished grade within $0.8 \mathrm{~km}(0.5 \mathrm{mi})$ of the plant. The other missiles can strike at any elevation. These criteria are based on recent revision of the WND-? tarnado criteria by KRC:

- Parrish, J. V., 1995, UNP-2, Operating License.MPF-21, Request for Approval to Revise Tornedo Design Criteria, (let ter G02-95-212 to U.S. Muclear Regulatory Comission, October 10), Washington Public Power Supply System, Richland, Washingtan

- Clifford, J. W., 1996, Revision of Tornado Design Criteria for the Washington Public Power Supply System (UPPSS) Nuclear Project Mo. 2 (LWP-2) (TAC No. 88626) (letter GI2-96-032 to J. V. Parrish, Washington Public Power Supply System, January 24), U.5. Regulatory Commission, Uashington, D.C.

'Geomatrix, 1996, Probabilistic Seismic Hazard Analysis DOE Hanford Site, Washington, WHC-s0-W236A-II-002, Rev. 1, prepared by Geomatrix Consul tants, Incorporated, for Westinghouse Hanford Company, Richland, Washington.

DOE Order 5480.28, Matural Phenomena Hazards Mitigation, U.S. Department of Energy, Washington, D.C.

DOE Standard 1020-94, Natural Phenomena Hazards Oesign and Evaluation Criteria for Department of Energy Facitities, U.S. Department of Energy, Washington, D.C.

ASCE, 1993, Minimm Design Loads for Building and Other structures, ASCE-7-93, American Society of Civil Engineers, New York, New York.

Sulandard Review Plan, NUREG-0800, U.S. Muclear Regulatory Commission, Hashington, D.C.

'ANSI/ANS, 1992 , Determining Design Basis flooding at Power Reactor Sites, ANSI/ANS-2.8-1992, American Nuclear Society, La Grange Park, Illinois.
WFPA, 1992, Lightning Protection, NFPA 780, National Fire Protection Association, Quincy, Massachusetts. 


\subsection{U.S. DEPARTMENT OF ENERGY DESIGN REQUIREMENTS}

Seismic design for Performance Category 3 projects shall follow, as a minimum, DOE Order 5480.28 and supporting standard DOE-STD-1020-94, Chapter 2 and Appendix $C$. Equal-hazard 5\% damped horizontal and vertical response spectra anchored at $0.26 \mathrm{~g}$ horizontal are shown in Figure 2. Table 2 provides spectral values for the various damping values that may be required for design. In-structure response spectra need to be generated for structures, systems, and components supported by the structure. Performance Category 1 and 2 structures, systems, and components shall use the Uniform Building Code (ICBO 1994), Zone 2B, as discussed in DOE-STD-1020-94. Standard occupancy rules shall be used for Performance Category 1 and essential facilities rules for Performance Category 2.

\subsection{WIND AND TORNADO CRITERIA}

\subsection{BACKGROUND}

The Hanford Site is located in a semiarid region of southeastern Washington. The Cascade Range to the west greatly influences the climate of the Hanford Site by causing a rain shadow effect. This mountain range also serves as a source of cold air drainage, which has considerable effect on the wind regime of the Hanford Site.

Data have been collected since 1945 at the Hanford Meteorological Station, located between the Hanford Site's 200 East and West Areas. This includes wind data from six levels on a $125-\mathrm{m}-(410-\mathrm{ft}-)$ high tower. These data are supplemented with data from 2.6 monitoring stations on and around the Hanford Site. The most recent compilation of these data is in PNL-9809, Hanford Site Climatological Data Summary 1993 with Historical Data (Hoitink and Burk 1994).

\subsection{U.S. DEPARTMENT OF ENERGY DESIGN REQUIREMENTS}

Two probabilistic wind hazard assessments have been completed for the Hanford Site. The first assessment was completed by Lawrence Livermore National Laboratory and reported in UCRL-53526, Natural Phenomena Hazards Modeling Project: Extreme Wind/Tornado Hazard Models for Department of Energy Sites (Coats and Murray 1985). This assessment was based on more than 30 years of pre-1979 Hanford Site winc data. The results are shown in Figure 3 and are the basis for the recommended wind speeds for the Hanford Site 1 isted in DOE-STD-1020-94, Table 3-2. The wind missiles are 1isted in DOE-STD-1020-94, Table 3-1. 
Figure 2. Performance Category 3 Horizontal and Vertical Design Response Spectra with 5\% Damping at the Site of the Cold Vacuum Drying System.

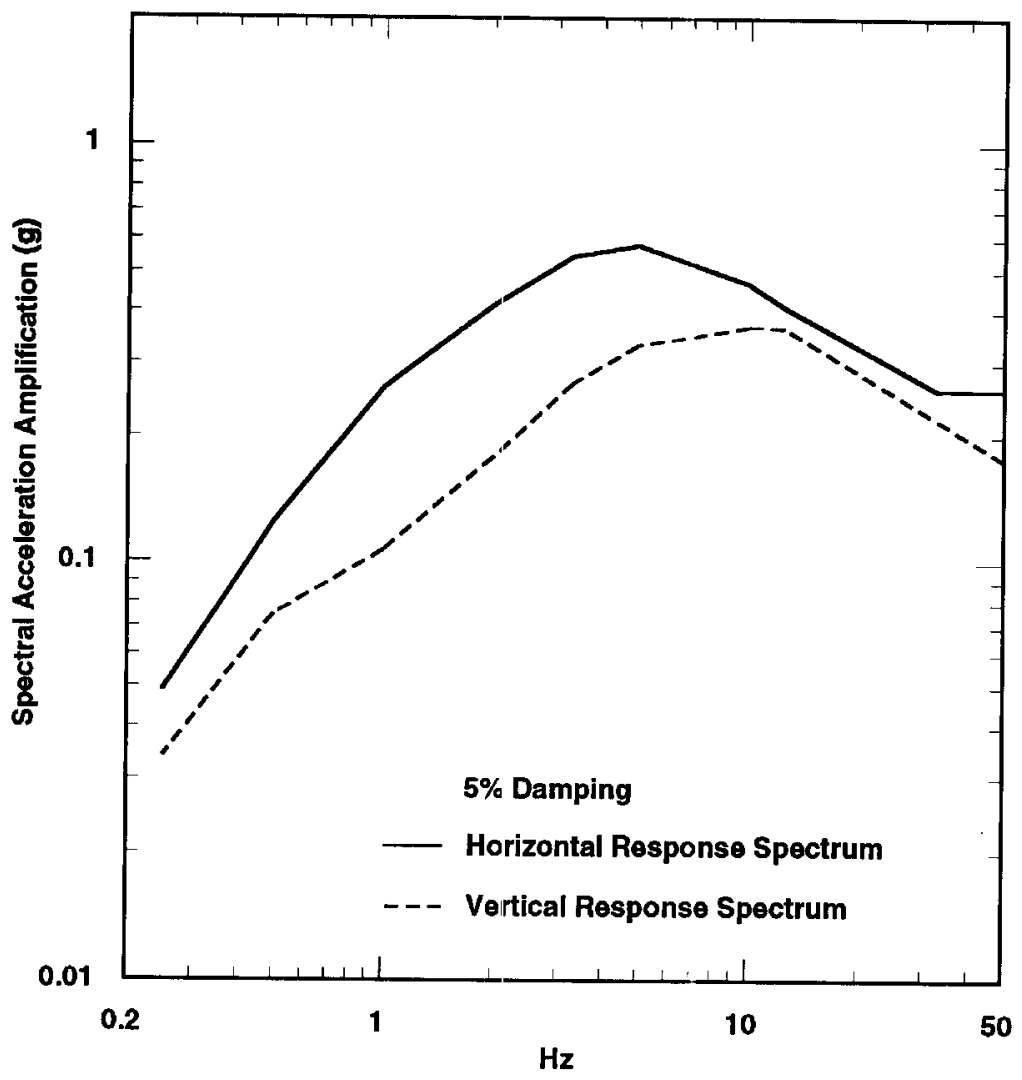

H96010294.5 
Table 2. Cold Vacuum Drying System Design Response Spectra.

\begin{tabular}{|c|c|c|c|c|c|c|}
\hline \multirow{2}{*}{$\begin{array}{c}\text { Frequency } \\
\text { (Hertz) }\end{array}$} & \multicolumn{7}{|c|}{ Damping } \\
\cline { 2 - 7 } & $0.5 \%$ & $2 \%$ & $5 \%$ & $7 \%$ & $10 \%$ & $12 \%$ \\
\hline \multicolumn{7}{|c|}{ Horizonta 1 response spectra $(g)$} \\
\hline 33.3 & 0.26 & 0.26 & 0.26 & 0.26 & 0.26 & 0.26 \\
\hline 13.3 & 0.57 & 0.48 & 0.41 & 0.38 & 0.36 & 0.35 \\
\hline 10 & 0.77 & 0.59 & 0.47 & 0.43 & 0.38 & 0.36 \\
\hline 5 & 1.04 & 0.76 & 0.58 & 0.52 & 0.45 & 0.42 \\
\hline 3.3 & 0.98 & 0.72 & 0.54 & 0.48 & 0.42 & 0.39 \\
\hline 2 & 0.74 & 0.55 & 0.41 & 0.37 & 0.33 & 0.30 \\
\hline 1 & 0.45 & 0.34 & 0.26 & 0.23 & 0.21 & 0.19 \\
\hline 0.5 & 0.22 & 0.17 & 0.13 & 0.12 & 0.11 & 0.10 \\
\hline 0.25 & 0.08 & 0.06 & 0.05 & 0.65 & 0.04 & 0.04 \\
\hline & & 0.26 & 0.26 & 0.26 & 0.26 & 0.26 \\
\hline 100 & 0.18 & 0.18 & 0.18 & 0.18 & 0.18 & 0.18 \\
\hline 50 & 0.18 & 0.18 & 0.18 & 0.18 & 0.18 & 0.18 \\
\hline 13.3 & 0.60 & 0.46 & 0.37 & 0.33 & 0.30 & 0.28 \\
\hline 10 & 0.66 & 0.49 & 0.37 & 0.33 & 0.29 & 0.27 \\
\hline 5 & 0.60 & 0.44 & 0.33 & 0.30 & 0.26 & 0.24 \\
\hline 3.3 & 0.48 & 0.36 & 0.27 & 0.24 & 0.21 & 0.19 \\
\hline 2 & 0.32 & 0.24 & 0.18 & 0.16 & 0.14 & 0.13 \\
\hline 1 & 0.19 & 0.14 & 0.11 & 0.10 & 0.09 & 0.08 \\
\hline 0.5 & 0.14 & 0.11 & 0.08 & 0.07 & 0.07 & 0.06 \\
\hline 0.25 & 0.06 & 0.05 & 0.04 & 0.03 & 0.03 & 0.03 \\
\hline
\end{tabular}


Figure 3. Straight Wind and Tornado Hazards. (Straight Wind Speeds in Fastest Mile).

Wind Speed (metere/sec)

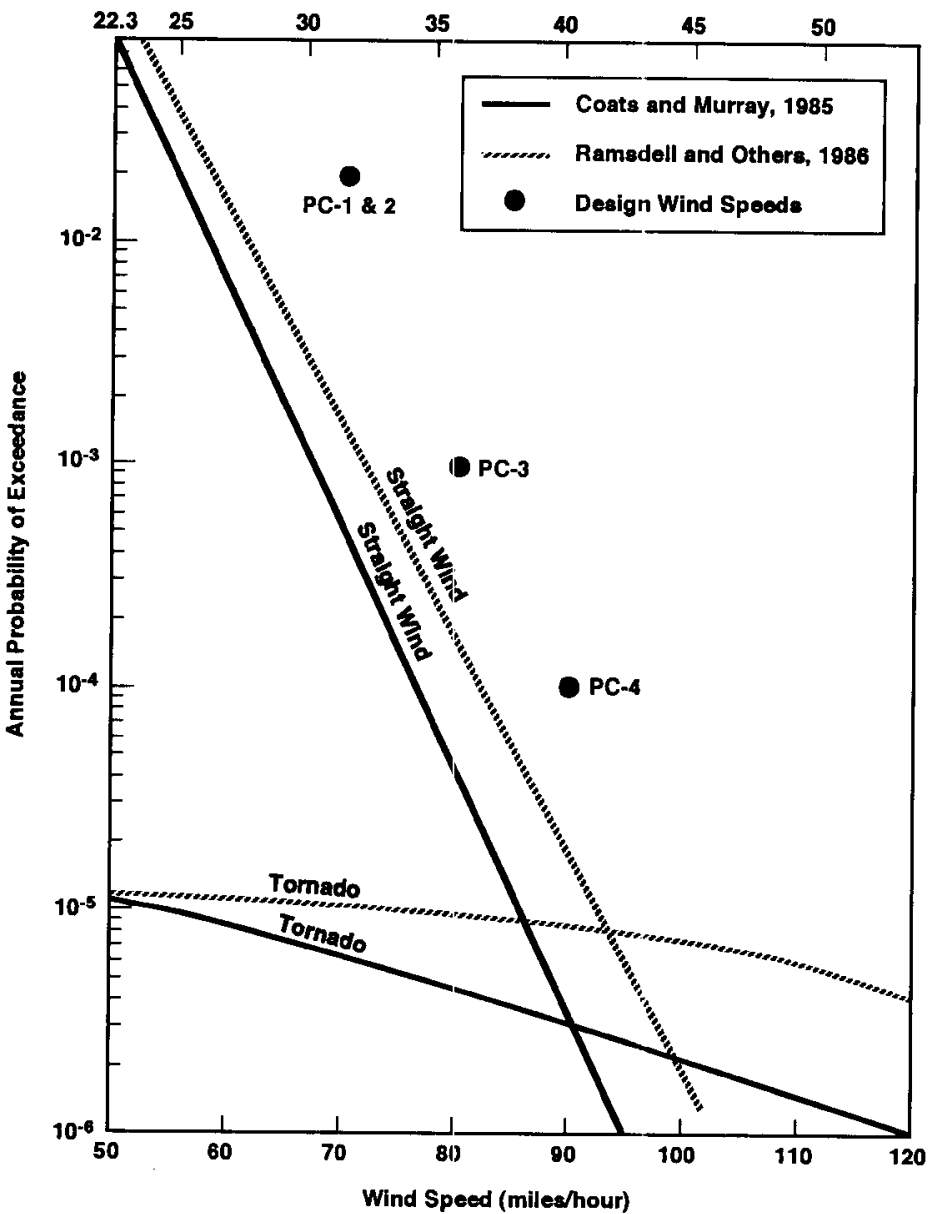

Ho5120284.1 
A second study, NUREG/CR-4492, Methodology for Estimating Extreme Winds for Probabilistic Risk Assessments (Ramsdell et al. 1986), describes a procedure for estimating extreme wind probabilities. The application of this methodology to Hanford Site data, including post-1979 data, resulted in the hazard curves shown in Figure 3 . There are no known local meteorological events or changes in methodology since 1986 that would cause significant changes to the Hanford Site wind hazard.

The wind hazard annual probability of exceedance for Performance Categories 1 and 2 is $2 \times 10^{-2}$ (DOE-STD-1020-94). On Figure 3 , this is about $25 \mathrm{~m} / \mathrm{s}(55 \mathrm{mi} / \mathrm{h})$ on the Coats-and-Murray curve and about $26 \mathrm{~m} / \mathrm{s}(58 \mathrm{mi} / \mathrm{h})$ on the Ramsdell-and-0thers curve. However, a minimum design wind speed of $31.3 \mathrm{~m} / \mathrm{s}(70 \mathrm{mi} / \mathrm{h})$ is required by the American Society of Civi? Engineers in ASCE-7-93, Minimum Design Loads for Building and Other Structures (ASCE 1993), and recommended by DOE-STD-1020-94. Therefore, the Hanford Site design basis wind speed for Performance Categories 1 and 2 is $31.3 \mathrm{~m} / \mathrm{s}(70 \mathrm{mi} / \mathrm{h})$. All wind speeds are fastest-mile speeds at $9 \mathrm{~m}(30 \mathrm{ft})$ off the ground.

The straight wind hazard exceedance probability for Performance Category 3 is $1 \times 10^{-3}$. On Figure 3 , this is approximately $30 \mathrm{~m} / \mathrm{s}(67 \mathrm{mi} / \mathrm{h})$ on the Coats-and-Murray curve and $32 \mathrm{~m} / \mathrm{s}(72 \mathrm{mi} / \mathrm{h})$ on the Ramsdell-and-0thers curve. In DOE-STD-1020-94, the minimum straight wind speed for Performance Category 3 design is $35.8 \mathrm{~m} / \mathrm{s}(80 \mathrm{mi} / \mathrm{h})$, which is higher than either of the wind hazard studies and is, therefore, the design basis for the site. A $6.81-\mathrm{kg}$ (15-1b) timber plank missile, $0.61 \mathrm{~m} \times 1.22 \mathrm{~m}(2 \mathrm{ft} \times 4 \mathrm{ft})$, is applied to Performance Category 3 structures, systems, and components at $22.4 \mathrm{~m} / \mathrm{s}(50 \mathrm{mi} / \mathrm{h})$ to a height of $9 \mathrm{~m}(30 \mathrm{ft})$. These wind criteria are higher than the NRC requirements and are appijed to the CVSS.

The intersection of the straight wind and tornado hazard curves determines whether tornadoes should be included in the design and evaluation criteria (Coats and Murray 1985). If the exceedance probability at the intersection is less than $2 \times 10^{-5}$, straight winds control the design criteria. In Figure 3 , this intersection is at $3 \times 10^{-6}$ on the Coats-andMurray curves and at $8 \times 10^{-6}$ on the Ramsde11-and-0thers curves. Therefore, following DOE guidance, the Hanford Site does not have a DOE design basis tornado.

\subsection{U.S. NUCLEAR REGULATORY COMMISSICN DESIGN REQUIREMENTS}

The guidance in 10 CFR 72 with respect to straight wind and tornado hazard mitigation is very general and nonprescriptive (10 CFR 72.122[b]). The Standard Review Plan section on wind loading (NRC 1981, Section 3.3.1) is specific and serves as a basis for determining appropriate straight wind and tornado values for the CVDS because it has been accepted by the NRC for issuing the materials licenses for such facilities. The 100-year, fastest-mile wind speed is used for the straight wind calculations using American Society of Civil Engineers methodology (ASCE 1993, ASCE 1961). The 100 -year (10 $0^{-2}$ annual probablility of exceedance), fastest-mile wind at the Hanford Site is about $105 \mathrm{~km} / \mathrm{h}$ (65 mi/h) (Figure 3). However, because DOE-STD-1020-94 requires a minimum of $129 \mathrm{~km} / \mathrm{h}(80 \mathrm{mi} / \mathrm{h})$ for Performance Category 3, the higher DOE value will be used for the design of the CVDS. 
Washington Public Power Supply System (Supply System) Nuclear Plant 2 (WNP-2), located on property within the boundaries of the Hanford Site, was 1 icensed to use tornado design wind speeds of $483 \mathrm{~km} / \mathrm{h}(300 \mathrm{mi} / \mathrm{h})$ rotatjonal and $97 \mathrm{~km} / \mathrm{h}(60 \mathrm{mi} / \mathrm{h})$ translational, with a pressure drop of $2,109 \mathrm{~kg} / \mathrm{m}^{2}$ ( $\left.31 \mathrm{~b} / \mathrm{in}^{2}\right)$ occurring at $703 \mathrm{~kg} / \mathrm{m}^{2} / \mathrm{s}\left(1.01 \mathrm{~b} / \mathrm{in}^{2} / \mathrm{s}\right)$. These wind speeds are higher than would be required by Regulatory Guide 1.76, Design Basis Tornado for Nuclear Power Plants (NRC 1974). Regulatory Guide 1.76 indicates that the Hanford Site is in tornado Region III for which the criteria are $305 \mathrm{~km} / \mathrm{h}$ $(190 \mathrm{mi} / \mathrm{h})$ rotational and $80 \mathrm{~km} / \mathrm{h}(50 \mathrm{mi} / \mathrm{h})$ translational, with a $1,055 \mathrm{~kg} / \mathrm{m}^{2}$ $\left(1.5 \mathrm{lb} / \mathrm{in}^{2}\right)$ pressure drop at $422 \mathrm{~kg} / \mathrm{m}^{2} / \mathrm{s}\left(0.6 \mathrm{lb} / \mathrm{in}^{2} / \mathrm{s}\right)$. The NRC staff have proposed dividing the United States into two regions and making the total rotational and translation wind speeds for sites west of the Rocky Mountains $322 \mathrm{~km} / \mathrm{h}(200 \mathrm{mi} / \mathrm{h}$ ) (NRC 1993). The bas is for this consideration is a tornado hazards study, NUREG/CR-4461, Tornado Climatology of the Contiguous United States (Ramsdell and Andrews 1986). The Supply System requested (Parrish 1995; see Appendix A) a revision of the WNP-2 tornado criteria based upon the NRC staff's proposal for torluado wind speeds west of the Rocky Mountains (NRC 1993) and on the staff's acceptance of the design basis tornado characteristics in NUREG-1503, Final Safety Evaluation Report Related to the Certification of the Advanced Boiling Water Reactor Design (NRC 1994). The impact velocities for the proposed tornado missile spectrum based on the reduced wind speed of $322 \mathrm{~km} / \mathrm{h}(200 \mathrm{mi} / \mathrm{h})$ were calculated by the Supply System. The NRC accepted the proposed lower tornado missile criteria (Clifford 1996; see Appendix B). The design of structures can be performed by using the tornado wind speeds and missiles below or by addressing the need for protection of specific targets on a risk assessment basis, as presented after the missile description. The CVDS tornado design requirements, including design missiles, are listed below:

- Wind speed

- $322 \mathrm{~km} / \mathrm{h}(200 \mathrm{mi} / \mathrm{h})$ totial

- $257 \mathrm{~km} / \mathrm{h}(160 \mathrm{mi} / \mathrm{h})$ rotational

- $64 \mathrm{~km} / \mathrm{h}(40 \mathrm{mi} / \mathrm{h})$ transiational

- Pressure drop

- 6,205 $\mathrm{Pa}\left(0.90 \mathrm{lb} / \mathrm{in}^{2}\right)$ at $2,068 \mathrm{~Pa} / \mathrm{s}\left(0.30 \mathrm{lb} / \mathrm{in}^{2} / \mathrm{s}\right)$

- Missiles

- Wood plank

$52 \mathrm{~kg}(115 \mathrm{lb})$

$0.092 \mathrm{~m} \times 0.289 \mathrm{~m} \times 3.66 \mathrm{~m}(3.6 \mathrm{in.} \times 0.94 \mathrm{ft} \times 12 \mathrm{ft})$

$49.3 \mathrm{~m} / \mathrm{s}(161.7 \mathrm{ft} / \mathrm{s})$ horizontal impact velocity

- 6-in. schedule 40 pipe

$130 \mathrm{~kg}$ (287 1b)

$0.168 \mathrm{~m}$ diameter $\times 4.58 \mathrm{~m}(6.6 \mathrm{n}$. diameter $\times 15 \mathrm{ft})$

$8.2 \mathrm{~m} / \mathrm{s}(27.0 \mathrm{ft} / \mathrm{s})$ horizontal impact velocity 
- 2.5-cm (1-in.) steel rod

$4 \mathrm{~kg}(8.8 \mathrm{lb})$

$0.0254 \mathrm{~m}$ diameter $\times 0.915 \mathrm{~m}$ ( $1 \mathrm{in}$. diameter $\times 3 \mathrm{ft}$ )

$7.6 \mathrm{~m} / \mathrm{s}(24.9 \mathrm{ft} / \mathrm{s})$ horizontal impact velocity

- Utility pole

$510 \mathrm{~kg}(1,124 \mathrm{lb})$

$0.343 \mathrm{~m}$ diameter $\times 10.68 \mathrm{~m}$ (13.5 in. diameter $\times 35 \mathrm{ft}$ )

$9.4 \mathrm{~m} / \mathrm{s}(30.7 \mathrm{ft} / \mathrm{s})$ horizontal impact velocity

- 12-in. schedule 40 pipe

$340 \mathrm{~kg}(750 \mathrm{lb})$

$0.32 \mathrm{~m}$ diameter $\times 4.58 \mathrm{~m}(12.75 \mathrm{in}$. diameter $\times 15 \mathrm{ft})$

$6.6 \mathrm{~m} / \mathrm{s}(21.8 \mathrm{ft} / \mathrm{s})$ horizontal impact velocity

- Automobile

$1,810 \mathrm{~kg}(3,990 \mathrm{lb})$

$5 \mathrm{~m} \times 2 \mathrm{~m} \times 1.3 \mathrm{~m}(16.4 \mathrm{ft} \times 6.6 \mathrm{ft} \times 4.3 \mathrm{ft})$

$32.1 \mathrm{~m} / \mathrm{s}(105.2 \mathrm{ft} / \mathrm{s})$ horizontal impact velocity.

The missiles are considered to strike surfaces in any direction, and the vertical velocities are $70 \%$ of the horizontal velocities except for the $2.5-\mathrm{cm}$ (1-in.) steel rod, which has the same velocity in any direction. The utility pole and automobile are considered to strike surfaces up to a maximum of $9.1 \mathrm{~m}(30 \mathrm{ft})$ above the highest finished grade within $0.8 \mathrm{~km}(0.5 \mathrm{mi})$ of the plant. The other missiles can strike at any elevation.

An alternative to providing tornado missile protection for all safetyclass and important-to-safety structures, systems, and components is to address the need for protection of specific targets on a risk assessment basis. By this process, an estimate is made of the probability that a tornado-generated missile will strike a particular target and fail the target in such a way that unacceptable consequences result. For facilities with relative small targets areas, the risk assessment can simply investigate the probability that a missile strikes a target. If the probability obtained of a missile striking and failing a target. or simply striking the target, satisfies established acceptance criteria, then no physical barriers against missiles need be provided.

The use of probabilistic risk assessment techniques to establish the need to provide tornado-generated missile protection for specific targets has been accepted by the NRC for several years and is well documented in their review and design guidance. For example, the NRC Standard Review Plan (NRC 1981), Section 3.5.1.5, "Site Proximity Missiles (Except Aircraft), " includes the following statement relative to low risk of exposure to the public.

This requirement is met if the probability of site proximity missiles impacting the plant and causing radiological consequences greater than 10 CFR Part 100 exposure guidelines is less than about $10^{-7}$ per year (see SRP Section 2.2.3). 
The NRC Standard Review Plan (NRC, 1981), Section 2.2.3, "Evaluation of Potential Accidents, " accepts $10^{-6}$ events/yr for offsite hazards exceeding the guidelines in Title 10, Code of Federal Regulations, Part 100, "Reactor Site Criteria" (10 CFR 100), if, when accompanied by reasonable qualitative arguments, the realistic value can be shown to be lower. For the CSB, an acceptance criterion to not exceed the $5 \mathrm{rem}(50 \mathrm{mSV}$ ) 1 imit of 10 CFR 72.106 at the controlled area boundary should be used.

The probability of a tornado occurring near the site and generating a missile that results in acceptable consequences can be expressed as follows:

$$
P_{T M}=P_{s} \times P_{m s} \times P_{F} \times P_{D}
$$

where

$P_{T M}=$ The annual probability of a tornado missile striking such that an unacceptable radiological or chemical release occurs

$P_{s}=$ The tornado annual point st.rike frequency (events/yr)

$P_{m s}=$ The probability of a tornaclo-generated missile impacting a specific target (this includes the probabilities of the missile existing on the site, being lifted, and striking the target of a given area)

$P_{F}=$ The probability of target failure as a result of being struck by a missile (this considers that not all missiles that strike the target will be of sufficient energy to $f a i l$ the target)

$P_{D}=$ The probability, given the failure of the target by a missile, that unacceptable radiological or chemical release occurs (this considers that not all target failures will be of sufficient severity to result in unaccieptable consequences).

The above expression is simplified in that the analyses are usually performed for a range of tornado interisities and potential missiles. The tornado intensities considered are based upon available local severe weather data. The missiles considered vary in terms of their density on the site, ability to be lifted by a tornado of a given intensity, and ability to damage the target. The missiles appropriate for consideration are often established by a site survey with a radius of about $600 \mathrm{~m}(2,000 \mathrm{ft})$.

It should be noted in the above equation that the missile selection is based upon realistic selection of potential missiles based upon a site survey. 
WHC-SD-SNF-DB-010 REV 1

\subsection{VOLCANIC ASH CRITERIA}

\subsection{BACKGROUND}

Volcanic hazards that have affected the Hanford Site in the past 20 million years are of two types: (1) continental flood basalt volcanism that produced the Columbia River Basalt Group, which underlies the Hanford Site, outcropping in the surrounding ridges; and (2) volcanism associated with the Cascade Range. Several volcanoes in the Cascade Range are currently considered to be active, but activity associated with flood basalt volcanism has ceased.

The flood basalt volcanism that produced the Columbia River Basalt Group occurred between 17 million and 6 million years before present (BP). Most of the lava was extruded during the first: 2 to $2.5 \mathrm{milli}$ ion years of the 11-million-year volcanic episode. Volcanic activity has not recurred during the last 6 million years, suggesting cessation of the tectonic processes that created the episode. The recurrence of Columbia River basalt volcanism is not considered to be a credible volcanic hazard (DOE 1988).

The Cascade Range has been volcarically active throughout the Pleistocene epoch (approximately 2 million years BP to 10,000 years BP) and the Holocene epoch $(10,000$ years BP to present). The eruption history of the Holocene best characterizes the most likely types of activity in the next 100 years. Many of the volcanoes have been active in the last 10,000 years, including Mount Mazama (Crater Lake) and Mount Hood ir Oregon, and Mount St. Helens, Mount Adams, and Mount Rainier in Washingtor. The Hanford Site is approximately $150 \mathrm{~km}$ (95 mi) from Mount Adams, $175 \mathrm{~km}$ (110 mi) from Mount Rainier, and $200 \mathrm{~km}$ (125 mi) from Mount St. Helens, the three cl jsest active volcanoes. At these distances, tephra (ash) is the only hazard. Mount St. Helens has been considerably more active throughout the Holocene than Mount Rainier or Mount Adams, which is the least active of the three.

Probabilistic volcanic hazard studies of the Cascade Range have been completed by the U.S. Geological Survey (Hoblitt et al. 1987, Scott et a1. 1995). Figure 4 illustrates the annual probability of exceeding $1 \mathrm{~cm}$ of volcanic ash accumulation in Washirgton and Oregon following the eruption of a major Cascade Range volcano, and Figure 5 illustrates the annual probability of exceeding $10 \mathrm{~cm}$ of volcanic ash accumulation. Figure 6 presents this information as a volcanic ash hazard surve for the Hanford Site.

\subsection{U.S. DEPARTMENT OF ENERGY DESIGN REQUIREMENTS}

DOE has no specific orders or standards setting design criteria for ash loads. Criteria for determining desic|n basis ash loads were developed specificaliy for the Hanford Site (Salmon 1996) to ensure that the performance goals of DOE Order 5480.28 are met. The design basis ashfall 1 oads and recommended risk reduction factors for the Hanford Site given in Table 3 are based on the hazard curve shown in Figure 6 . For Performance Categories 1, 2, and 3 , ashfall need not be considered because it is not a controlling load when using the load combinations for the design and analysis found in 
Figure 4. Annual Probabilitiy of One Centimeter or More of Volcanic Ash Accumulation in Washington and Oregon from Major Cascade Range Volcanoes.

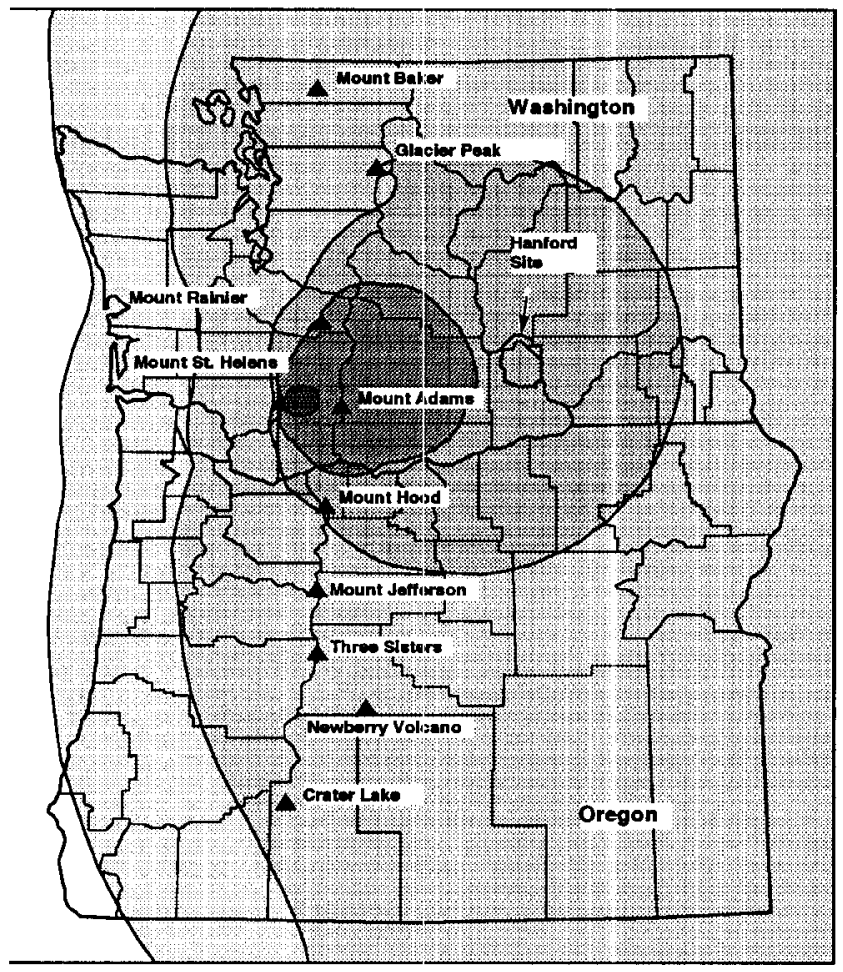

$1 \%$

$0.2 \%$

$0.1 \%$

$0.02 \%$

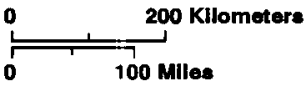

$0.01 \%$

Less Than $0.01 \%$

H96010294.11 cVDE Rov 4PC 
Figure 5. Annual Probability of 10 Centimeters or More of Volcanic Ash Accumulation in Washington and Oregon from Major Cascade Range Volcanoes.

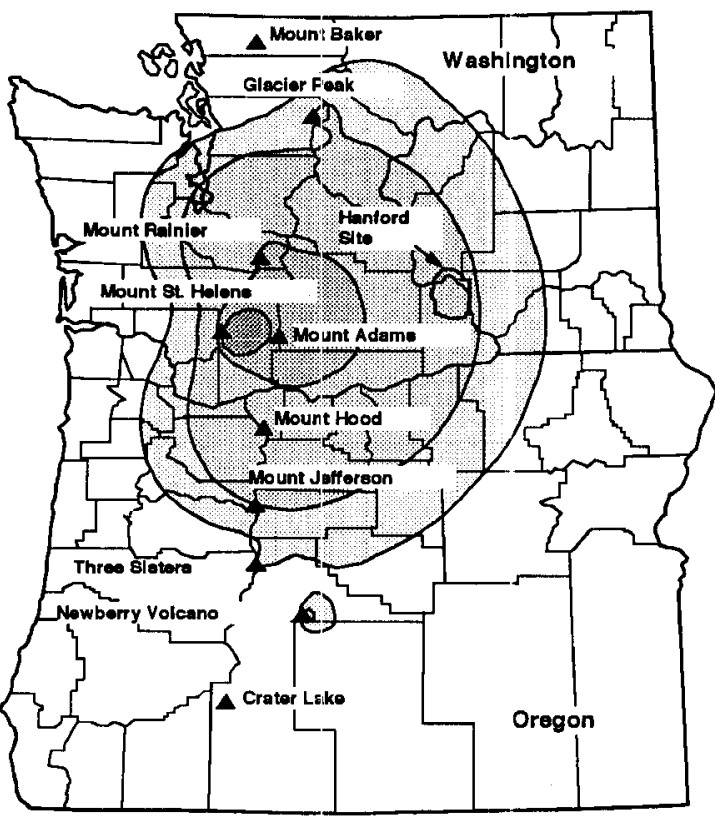

$1 \%$

$0.2 \%$

$0.1 \%$

$0.02 \%$

$0.01 \%$

Lees Than $0.01 \%$

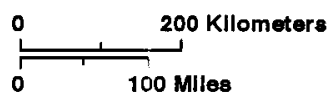

7G96040260.1 CVDS 
WHC-SD-SNF-DB-010 REV :

Figure 6. Cascade Range Volcanic Ash Hazard.

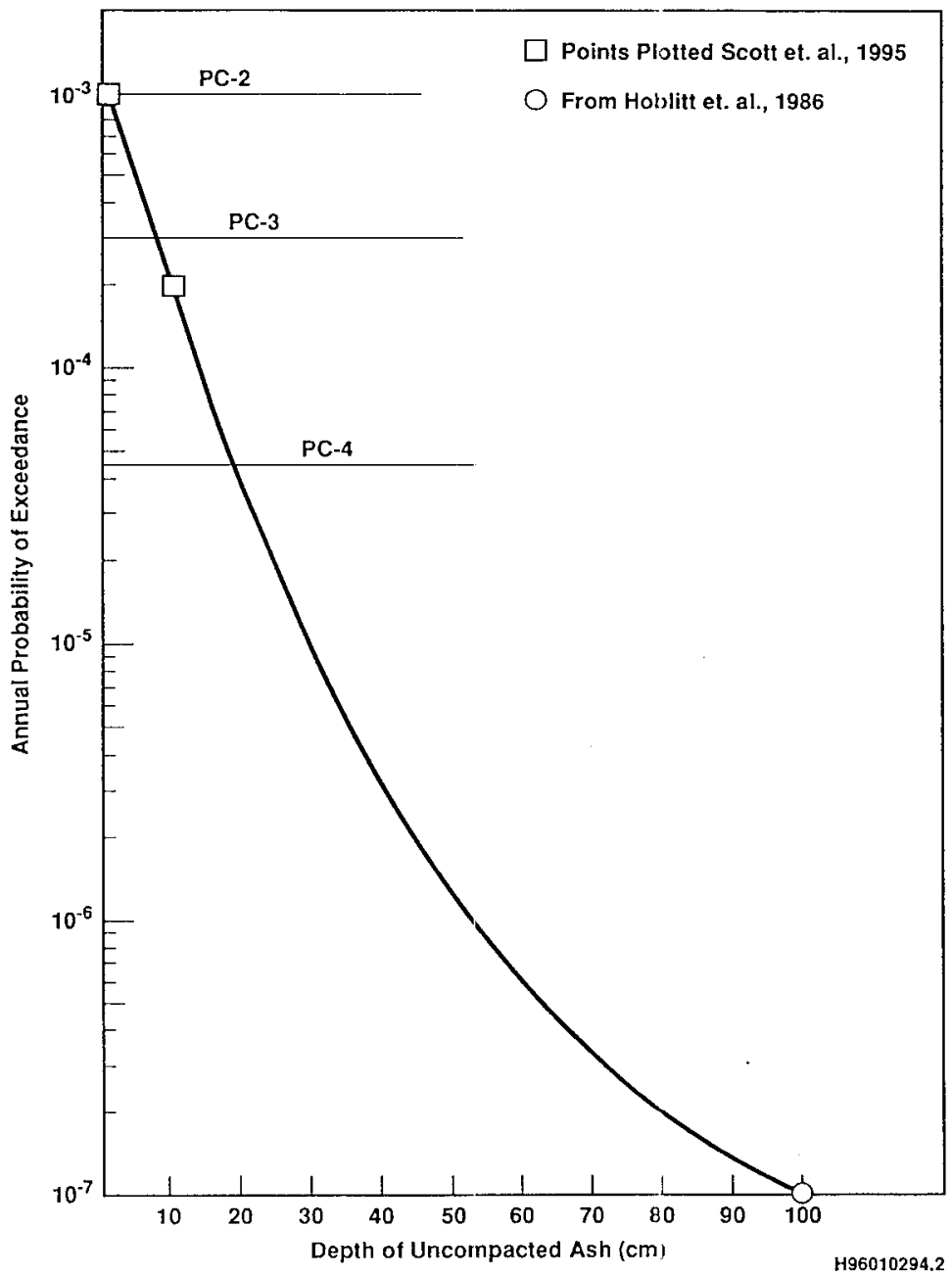


Table 3. Design Basis loads for Ashfall Criteria.

\begin{tabular}{|c|c|c|c|c|c|}
\hline $\begin{array}{c}\text { Performance } \\
\text { category }\end{array}$ & $\begin{array}{c}\text { Target } \\
\text { performance goal } \\
\left(\mathrm{P}_{\mathrm{i}}\right)\end{array}$ & $\begin{array}{c}\text { Hazard curve } \\
\text { slope paramiter } \\
\left(\mathrm{A}_{8}\right)\end{array}$ & $\begin{array}{c}\text { Risk reduction } \\
\text { factor }\end{array}$ & $\begin{array}{c}\text { Ash hazard } \\
\text { probability } \\
\left(\mathrm{P}_{\mathrm{n}}\right.\end{array}$ & $\begin{array}{c}\text { Design } \\
\text { ashfall load } \\
\left(\mathrm{kg} / \mathrm{m}^{2}\right)\end{array}$ \\
\hline 1 & $1 \times 10^{-3}$ & 5.0 & 2.1 & $2.1 \times 10^{-9}$ & 14.6 \\
\hline 2 & $5 \times 10^{-4}$ & 5.0 & 2.1 & $1.05 \times 10^{-3}$ & 24.4 \\
\hline 3 & $1 \times 10^{-4}$ & 3.1 & 3.0 & $3.0 \times 10^{-4}$ & 61 \\
\hline 4 & $1 \times 10^{-5}$ & 2.0 & 4.3 & $4.3 \times 10^{-5}$ & 146.5 \\
\hline
\end{tabular}

Note: Information in this table is from Salmon, M., 1996, Volcanic Ashfall Loads for the Hanford Site, WHC-SD-GN-ER-30038, ReV. O, Westinghouse Hantord Company, Richland, Washington.

DOE-STD-1020-94. Ashfall is considered an extreme environmental load and is not combined with other extreme environmental loads.

Operations that require air filtration or heating, ventilation, or air conditioning throughout an ashfall event must consider the impact of suspended ash on the operation. Unlike most other NPHs, some level of warning precedes volcanic hazards, especially distal ashfall. First, there is almost always increased seismic activity at the volcano, occurring from days to years before large eruptions. Further, heat gradients often increase, steam and smaller eruptions may be emitted from the volcano, and measurable deformation may occur on the volcano's surface. All these warnings provide a general alert and increase emergency preparedness in the immediate area of the volcano as well as downwind in an area like the Hanford Site. Second, ash from the closest active volcanoes would take approximately 2 hours to reach the Hanford Site (Scheidegger et al. 1982). This shorter warning time is for the much higher probability that the ash will affect the Site and may lend itself to administrative controls for ashfall mitigation. Administrative procedures implemented after an eruption should be used when mitigation can be achieved through evacuation; reconfiguration of the structure, system, or component; shutdown of operations; or other activities appropriate for the specific facility or operation. Should it be cletermined that a safe configuration cannot be achieved during the 2-hour warning time preceding the ashfall, the appropriate suspended ash load will be determined.

\subsection{U.S. NUCLEAR REGULATORY COMMISSION DESIGN REQUIREMENTS}

There is no NRC design requirement or regulatory guide for volcanic hazards, namely ashfall. The Supply System's Hanford Site design basis for ashfall for safety-related structures, systems, and components is $117 \mathrm{~kg} / \mathrm{m}^{2}$ $\left(24 \mathrm{lb} / \mathrm{ft}^{2}\right)$, which represents $7.4 \mathrm{~cm}$ (3 in.) of compacted ash (NRC 1982) with a dry compacted density of $1,538 \mathrm{~kg} / \mathrm{m}^{3}\left(96 \mathrm{bb} / \mathrm{ft}^{3}\right)$. This is about $15 \mathrm{~cm}$ (6 in.) of uncompacted ash. The Supply System ash load, which is larger than the DOE requirement, is applied to the CVDS.

As with the DOE requirements, the appropriate suspended ash load will be determined if required. 
WHC-SD-SNF-DB-010 REV 1

\subsection{FLOOD CRITERIA}

\subsection{BACKGROUND}

The CVDS facility site is at an elevation of about $140 \mathrm{~m}$ (460 ft) above mean sea level and approximately $0.8 \mathrm{~km}(0.5 \mathrm{~m})$ from the Columbia River (Figure 1). The level of the probable maximum flood at the $100 \mathrm{~K}$ Area, not considering potential dam failure, is approximately $131 \mathrm{~m}$ (430 ft) above mean sea level or about $9 \mathrm{~m}(30 \mathrm{ft})$ below the proposed CVDS site (ERDA 1976). The flood that results from a $25 \%$ breach of Grand Coulee Dam is estimated to reach $140 \mathrm{~m}$ (460 ft) above mean sea 1eve1, which is approximately the level of the ground surface of the CVDS site.

\subsection{U.S. DEPARTMENT OF ENERGY DESIGN REQUIREMENTS}

\subsubsection{Local Runoff}

DOE guidance in DOE-STD-1020-94 states that the performance goals for structures, systems, and components must be satisfied when subjected to the design basis flood for local precipitation. This can be done through design features that provide sufficient runolf capacity and through facility strengthening. The performance goal is $1 \times 10^{-4}$ for a Performance Category 3 structure such as the CVDS. The probable maximum precipitation (PMP) is conservatively assumed to have an annual probability of exceedance of less than $1 \times 10^{-6}$ (ASCE 1988). The NRC requirement is the PMP, which is a lower probability storm and higher precipitation than the DOE requirement.

\subsubsection{River Flooding}

The Performance Category 3 flood level at the $100 \mathrm{~K}$ Area is based upon a probabilistic flood hazard assessment of the Columbia River performed as part of a safety evaluation of the Hanford Site's N Reactor (McCann and Boissonnade 1988). The most extreme toods on the Columbia River are likely to occur as a result of dam failure. Specifically, failure of Grand Coulee and Mica dams poses the greatest threat. Dam failure is most likely to be initiated by seismic events. Conservative estimates of the seismic capacity of upstream dams are based primarily on engineering judgment and the historic frequency of dam failures. See UCRL-?1069, Probabilistic Flood Hazard Assessment for the $\mathrm{N}$-Reactor, Hanford, Washington (McCann and Boissonnade 1988), for a detailed discussion of the hazard assessment. The Performance Category $3\left(1 \times 10^{-4}\right.$ probability of exceedance) flood level at the $100 \mathrm{~K}$ Area is estimated to be about $1 \$ 7 \mathrm{~m}(450 \mathrm{ft})$ above mean sea level (Tallman 1996).

\subsection{U.S. NUCLEAR REGULATORY CONMISSION DESIGN REQUIREMENTS}

NRC guidance in 10 CFR 72 says that "the facility must be sited so as to avoid to the extent possible the long-term and short-term adverse impacts 
associated with the occupancy and modification of floodplains." No guidance is given for the probabilities of flooding or precipitation to be addressed. The 24-hour PMP estimates are recommended for use in constructing runoff models for nuclear power reactors to estimate the discharge to the site's storm drainage system (NRC 1981, ANSI/ANS 1992).

\subsubsection{Local Runoff}

The PMP is used to assess local runoff and flood protection from intense precipitation for NRC power reactor design. A recent cooperative study by the National Oceanic and Atmospheric Administration, the Bureau of Reclamation, and the Corps of Engineers has updated the PMP estimates for the Pacific Northwest (Hansen et al. 1994). This document supersedes other earlier work done by these organizations and is the source used for the PMPs shown in Table 4. The PMP values are estimates of the maximum precipitation physically possible for both general storms (large air mass interactions) and local storms (unstable air, thunderstorms). At the Hanford Site the 6-hour local storm produces more precipitation than the 24-hour general storm. No annual probability of exceedance is given in Hydrometeorological Report No. 57, Probable Maximum Precipitation - Pacific Northwest States (Hansen et a1. 1994), for the PMP for either general or local storms.

At the Hanford Site, using the PMP for the local storm is more conservative than using the PMP for the general storm, which occurs over a larger area. The PMP for a local $1-\mathrm{m}^{2}{ }^{2}, 6$-hour storm $(23.4 \mathrm{~cm}[9.2 \mathrm{in.})$ will be used for the CVDS design (Table 4). The slightly lower $10-\mathrm{mi}^{2}$ rate (18.8 cm [7.4 in.] in 6 hours) will be used for calculating the surrounding watershed runoff.

\subsubsection{River Flooding}

The Columbia River flood design criterion for WNP-2 is the $25 \%$ breach of the Grand Coulee Dam (ERDA 1976). The elevation of this flood at the $100 \mathrm{~K}$ Area is about $140 \mathrm{~m}(460 \mathrm{ft}$ ) above mean sea level. This level is the design criterion to be applied to the CVDS facility as it exceeds the DOE requirement of $137 \mathrm{~m}(450 \mathrm{ft})$ by about: $3 \mathrm{~m}(10 \mathrm{ft})$.

\subsection{I.IGHTNING}

Neither DOE nor NRC have developed specific requirements for dealing with lightning. NFPA 780, Lightning Protes:tion (NFPA 1992), is recommended as guidance by DOE and NRC and will be applied for lightning protection for the CVDS facility. 
Table 4. Extreme Precipitation Estimates for the Hanford Site.

\begin{tabular}{|c|c|c|c|c|c|c|}
\hline Time & $\begin{array}{c}\text { PMP } \\
\text { 24-hour } \\
\text { general } \\
\text { storm } \\
\text { (in./10 mi } \text { ma }^{2}\end{array}$ & $\begin{array}{c}\text { PMP } \\
\text { local } \\
\text { storm } \\
\left(\text { in. } / 1 \mathrm{mi}^{2}\right)^{\mathrm{a}}\end{array}$ & $\begin{array}{c}\text { PMP } \\
\text { local } \\
\text { storm } \\
\left(\text { in. } / 10 \mathrm{mi}^{2}\right)^{a}\end{array}$ & $\begin{array}{l}25 \text {-year } \\
\text { average } \\
\text { return } \\
\text { period }^{b}\end{array}$ & $\begin{array}{l}\text { 100-year } \\
\text { average } \\
\text { return } \\
\text { period }\end{array}$ & $\begin{array}{c}1,000 \text {-year } \\
\text { average } \\
\text { return } \\
\text { period }^{b}\end{array}$ \\
\hline 15 minutes & - & 4.0 & 3.2 & -- & -- & -- \\
\hline 20 minutes & -- & -- & -- & 0.47 & 0.60 & 0.80 \\
\hline 45 minutes & -- & 7.2 & 5.8 & -- & -- & -- \\
\hline 1 hour & 1.6 & 8.0 & 6.4 & 0.62 & 0.81 & 1.11 \\
\hline 6 hours & 4.7 & 9.2 & 7.4 & 1.21 & 1.59 & 2.20 \\
\hline 24 hours & 8.0 & -- & -- & 1.56 & 1.99 & 2.68 \\
\hline
\end{tabular}

Note: To convert precipitation depths to cent imeters, multiply by 2.54 .

'Hansen, E. M., D. D. Fenn, P. Corrigan, J. L. Vogel, L. C. Schreiner, and R. W. Stodt, 1994, Probable Maximum Precipitation - Pacific Northwest States, Hydrometeorological Report No. 57, National Heather Service, Silver Spring, Maryland.

Worthest Nor thwest Laboratory, Richland, Washington.

PMP = probable maximm precipitation. 


\subsection{SNOW LOAD}

Both DOE and NRC recommend following ASCE-7-93 (ASCE 1993) for ground snow loads and design guidance. The Supply System's ground snow load of $98 \mathrm{~kg} / \mathrm{m}^{2}\left(20 \mathrm{lb} / \mathrm{ft}^{2}\right)$ is the design criterion to be applied to the CVDS facility.

\subsection{REFERENCES}

10 CFR 72, "Licensing Requirements for the Independent Storage of Spent Nuclear Fuel and High-Level Radiciactive Waste," Code of Federal Regulations, as amended.

10 CFR 100, "Reactor Site Criteria," Code of Federal Regulations, as amended.

ANSI/ANS, 1992, Determining Design Basis Flooding at Power Reactor Sites, ANSI/ANS-2.8-1992, American Nuclear Society, La Grange Park, Ill inois.

ASCE, 1961, "Wind Forces on Structures, " Transaction of the American Society of Civil Engineers, Vol. 126, Part II, American Society of Civil

Engineers, Washington, D.C.

ASCE, 1988, Evaluation Procedures for Hydrologic Safety of Dams, American Society of Civil Engineers, New Y'ork, New York.

ASCE, 1993, Minimum Design Loads for Building and Other Structures, ASCE-7-93, American Society of Civil Engineers, New York, New York.

Clifford, J. W., 1996, Revision of Tornado Design Criteria for the Washington Public Power Supply System (WPPSS) Nuclear Project No. 2 (WNP-2)

(TAC No. 88626) (letter GI2-96-0:12 to J. V. Parrish, Washington Public Power Supply System, January 24), U.S. Nuclear Regulatory Commission, Washington, D.C.

Coats, D. W. and R. C. Murray, 1985, Matural Phenomena Hazards Modeling Project: Extreme Wind/Tornado Hazard Models for Department of Energy Sites, UCRL-53526, Rev. 1, Lawrence Livermore National Laboratory, Livermore, California.

DOE, 1988, Site Characterization Plan, Consultation Draft, D0E/RW/0164, Vol. 1, U.S. Department of Energj', Washington, D.C.

DOE Order 5480.28, Natural Phenomena Hazards Mitigation, U.S. Department of Energy, Washington, D.C.

DOE-STD-1020-94, 1994, Natural Phenomena Hazards Design and Evaluation Criteria for Department of EnergJ Facilities, U.S. Department of Energy, Washington, DC.

DOE-STD-1022-94, 1994, Natural Phenomena Hazards Site Characteristics

Criteria, U.S. Department of Energy, Washington, D.C. 
DOE-STD-1023-95, 1995, Natural Phenomena Hazards As sessment Criteria, U.S. Department of Energy, Washirigton, D.C.

ERDA, 1976, Evaluation of Potential Flooding Criteria on the Hanford Project, RLO-76-4, U.S. Energy Research ard Development Agency, Washington, D.C.

Geomatrix, 1996, Probabilistic Seismic Hazard Analysis, DOE Hanford Site, Washington, WHC-SD-W236A-TI-002, Rev. 1, Prepared by Geomatrix Consultants, Incorporated, for Westinghouse Hanford Company, Richland, Washington.

Grumbiy, T. P., 1995, Concurrence with the K-Basins Spent Nuclear Fuel Project Policy on Nuclear Safety Requirenents, (Memorandum EM-36-3.1.6.7 to Manager, U.S. Department of Enercly, Richland Operations Office, July 20), U.S. Department of Energy, Washirgton D.C.

Hansen, E. M., D. D. Fenn, P. Corrigari, J. L. Vogel, L. C. Schreiner, and R. W. Stodt, 1994, Probable Maximum Precipitation - Pacific Northwest States, Hydrometeorological Report No. 57, National Weather Service, Silver Spring, Maryland.

Hoblitt, R. P., C. D. Miller, and W. E. Scott, 1987, Volcanic Hazards with Regard to Siting Nuclear-Power Plants in the Pacific Northwest, Open-File Report 87-297, U.S. Geological Survey, Cascades Volcano Observatory, Vancouver, Washington.

Hoitink, D. J., and K. W. Burk, 1994, Hanford Site Olimatological Data Summary 1993 with Historical Data, PNL-9809, Pacific Niorthwest Laboratory, Richland, Washington.

ICBO, 1994, Uniform Building Code, International Conference of Building officials, Whittier, California.

McCann, M. W. Jr., and A. C. Boissonnade, 1988, Probabilistic Flood Hazard Assessment for the N-Reactor, Harford, Washington, UCRL-21069, Lawrence Livermore National Laboratory, Livermore, California.

NFPA, 1992, Lightning Protection, NFPA 780, National Fire Protection Association, Quincy, Massachusetts.

NRC, 1974, Design Basis Tornado for Nuclear Power Plants, Regulatory Guide 1.76, U.S. Nuclear Regulatciry Commission, Washington, D.C.

NRC, 1981, Standard Review Plan, NUREG-0800, U.S. Nuclear Regulatory Commission, Washington, D.C.

NRC, 1982, Safety Evaluation Report Related to the Operation of WPPSS Nuclear Project No. 2, NUREG-0892, Supplement No. 1, U.S. Nuclear Regulatory Commission, Washington D.C.

NRC, 1993, Policy, Technical, and Licensing Issues Pertaining to Evolutionary and Advanced Light-Water Reactor (ALWR) Designs, SECY-93-087, U.S. Nuclear Regulatory Commissicn, Washington, D.C. 
NRC, 1994, Final Safety Evaluation Report Related to the Certification of the Advanced Boiling Water Reactor DE'sign, NUREG-1503, U.S. Nuclear Regulatory Commission, Washington, D.C.

Parrish, J. V., 1995, WNP-2, Operating License NPF-21, Request for Approval to Revise Tornado Design Criteria (1etter G02-95-212 to U.S. Nuclear Regulatory Commission, October 1C), Washington Public Power Supply System, Richland, Washington.

Ramsde11, J. V., and G. L. Andrews, 1986, Tornado Climatology of the Contiguous United States, NUREG/CR-4461, prepared for the U.S. Nuclear Regulatory Commission by Pacific Northwest Laboratory, Richland, Washington.

Ramsdel1, J. V., C. G. Elliott, C. G. Holladay, and J. M. Hubbe, 1986, Methodology for Estimating Extrenle Winds for Probabilistic Risk Assessments, NUREG/CR-4492, Prepared for the U.S. Nuclear Regulatory Commission by Pacific Northwest Laboratory, Richland, Washington.

Salmon, M., 1996, Volcanic Ashfall Loads for the Hanford Site, WHC-SD-GN-ER-30038, Rev. 0, Westinghouse Hanford Company, Richland, Washington.

Scheidegger, K. F., A. N. Federman, A. M. Tallman, 1982, "Compositional Heterogeneity of Tephras from the 1980 Eruptions of Mount St. Helens," Journal of Geophysical Research, Vol. 87, pp 10,861-10,881.

Scott, W. E., R. Iverson, M. Vallance, W. James, and W. Hildreth, 1995, Volcano Hazards in the Mount Adan's Region, Wasinington, Open-File Report 95-492, U.S. Geological Survey, Washing:on, D.C.

Stone, W. A., J. M. Thorp, O. P. Gifford, and D. J. Hoitink, 1983, Climatological Summary for the Hanford Site, PNL-4622, Pacific Northwest Laboratory, Richland, Washington.

Tallman, A. M., 1996, Natural Phenomena Hazards, Hanford Site, South-Central Washington, WHC-SD-GN-ER-501, Rev. 0, Westinghouse Hanford Company, Richland, Washington.

WHC, 1996, Spent Nuclear Fuel Project Seismic Design Criteria, Nuclear Regulatory Commission Equivalency Evaluation Report, WHC-SD-SNF-DB-004, Rev. 2, Westinghouse Hanford Company, Richland. Washington. 
WHC-SD-SNF-DB-010 REV 1

APPENDIX A

WNP-2, OPERATING LICENSE INPF-21, REQUEST FOR APPROVAL TO REVISE TORNADO DESIGN CRITERIA

A-1 
WHC-SD-SNF-DB-010 REV 1

This page intentionally left blank. 


$\frac{\text { WASHINGTON PUBLIC POWIER SUPPLY SYSTEM }}{\text { P. Box } 968 \cdot 3000 \text { George Washington Way } \cdot \text { Richland, Washingtor } 99352-09 \cdot 8 \cdot(509) 372.5000}$

October 10, 1995

GO2-95-212

Docket No. 50-397

U.S. Nuclear Regulatory Commission

Attn: Document Control Desk

Washington, D.C. 20555

Gentlemen:

Subject: WNP-2, OPERATING LICENSE NPF-21

REQUEST FOR APPROVAL TO REVISE TORNAIO DESIGN CRITERIA

References: 1) Letter G02-91-116, dated June 7, 1991, GC Sortnsen (SS) to NRC, same subject

2) Letter G02-94-001, dated Jan sary 6, 1994, JV Pirrish (SS) to NRC, same subject

3) Final Safety Evaluation Report Related to the Certification of the Advanced Boiling Water Reactor Design, NURJG-1503, July 1994

4) NUREG-0892, Safety Evaluation Report Rela ed to the Operation of WPPSS Nuclear Project No.2, March 1982

5) NUREG-0800, Standard Review Plan, June 1987

6) Regulatory Guide 1.76, April-1974, Design Ba is Tomado for Nuclear Power Plants.

By References 1 and 2, in accordance with the guidance of Reference 6. Section C.2, the Supply System requested approval to revise the WNP-2 tornado design criteria. Reference 1 requested that the total design basis tornado wind speed for WNP-2 be revised to $180 \mathrm{mph}$. Based on discussions with the staff, the Supply System revised its request vi Reference 2 to set the tomado design basis wind speed to $192 \mathrm{mph}$. Although the Supply ystem feels that each of these submitals is technically justified, the Supply System is hereby furher revising its request to establish the total design basis wind speed to $200 \mathrm{mph}$. The cur ent request is based on further discussions with the staif and is consistent with the design bas:s tomado characteristics accepted by the NRC in Reference 3 for the tornaco intensity region :ontaining WNP-2. The complete definition of the proposed design basis tomado characteristics including the proposed design basis missiles are provided in the attachment. 
Page 2

REQUEST FOR APPROVAT TO REVISE TOFNADO DESIGN CRITERIA

Should you have any questions or desire additional information regarding this matter, please call me or D. A. Swank at (509) 377-4563.

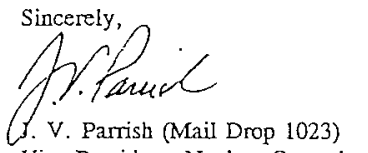

Vice President, Nuclear Operations

WLL/REB/ml

Attachment

cc: LU Callan - NRC RIV

KE Perkins, Jr. - NRC RIV, Walnut Creek Field Office

NS Reynolds - Winston \& Strawn

JW Clifford - NRC

DL Willians - BPA/399

NRC Sr. Resident Inspector - $927 \mathrm{~N}$ 
Attactument

WNP-2 current tornado design criteria, as stated in WNP-2 FSAR sections 2.3.1.2.1.3 and 3.3.2.1, are for wind speeds of $300 \mathrm{mph}$ rotational and $60 \mathrm{mph}$ translational, with a pressure drop of 3 psi to occur in 3 seconds. These criteria were found acceptable by the staff as documented in Reference 4, Section 3.3.2. The Supply System proposes to change the design criteria to 160 and $40 \mathrm{mph}$ rotational and translational velocities with a pressure drop of 0.90 psi occurring at $0.30 \mathrm{psi} / \mathrm{sec}$.

Relative to the requirements of Reference 6 , the current design requitements are conservative in that WNP-2 is a Region III site for which the criteria are $190 \mathrm{mph}$ rotational and $50 \mathrm{mph}$ translational with a 1.5 psi pressure drop at $0.6 \mathrm{psi} / \mathrm{sec}$. WNP-2 FSAR Section 3.3.2.4 and Appendix C.3 discuss the WNP-2 design relative to Reference 6 . It is apparent that the currently proposed criteria are less than those proposed by the Regulatory Guide for a Region III plant.

WNP-2 FSAR Section 3.5.1.4 establishes the following desigu basis tor nado generated missiles:

\begin{tabular}{|c|c|c|c|}
\hline Missile & $\begin{array}{c}\text { Weight } \\
(\mathrm{lbs})\end{array}$ & Dimensions & $\begin{array}{c}\text { Horizontal } \\
\text { Impact Velocity } \\
\text { (ft/sec) }\end{array}$ \\
\hline Utility Pole & 1600 & $14^{\prime \prime d i a} \times 35^{\prime}$ & 241 \\
\hline Steel Rod & 8 & $1^{\prime \prime}$ dia $\times 3^{\prime}$ & 259 \\
\hline
\end{tabular}

The NRC found these missiles acceptable in Section 3.5.1.4 of Reference 4.

Based upon the guidance of Reference 6, NRC approval of the use $00^{\circ}$ revised tornado design criteria is requested. The criteria are:

Wind Speeds:

200 mph maximum

$160 \mathrm{mph}$ rotational

40 mph translational

Pressure Drop:

0.90 psi

at $0.30 \mathrm{psi} / \mathrm{sec}$ 
Missiles:

\begin{tabular}{|c|c|c|c|}
\hline Missile & $\begin{array}{c}\text { Weight } \\
\text { (lbs) }\end{array}$ & Dimensions & $\begin{array}{c}\text { Horizontal } \\
\text { Impact } \\
\text { Velocity } \\
\text { (ft/sec) }\end{array}$ \\
\hline Wood Plank & 115 & $3.6^{\prime \prime} \times 0.94^{\prime} \times 12^{\prime}$ long & 161.7 \\
\hline $6^{\prime \prime}$ Sch 40 Pipe & 287 & $6.6^{\prime \prime}$ dia $\times 15^{\prime}$ long & 27.0 \\
\hline $1^{\prime \prime}$ Steel Rod & 8.8 & $1^{\prime \prime}$ dia $\times 3^{\prime}$ long & 24.9 \\
\hline Utility Pole & 1124 & $13.5^{\prime \prime}$ dia $\times 35^{\prime}$ long & 30.7 \\
\hline $12^{\prime \prime}$ Sch 40 & 750 & $12.75^{\prime \prime}$ dia $\times 15^{\prime}$ long & 21.8 \\
\hline Pipe & 3990 & $16.4^{\prime} \times 6.6^{\prime} \times 4.3^{\prime}$ & 105.2 \\
\hline Automobile & &
\end{tabular}

Consistent with Reference S, Section 3.5.1.4, these missiles are considered to strike surfaces in any direction. Vertical velocities are taken to be 70 percent of the horizontal velocities except for the $1 "$ steel rod which is assumed to have the same velocity in any direction. The utility pole and the automobile are considered to strike surfaces at any elevition up to a maximum elevation of 30 feet above the highest finished gradis within 0.5 miles of the plant. The other missiles are considered to strike at any elevation.

Based on Reference 5, Section 3.3.2, total tomado loads resulting from wind loads, differential pressure loads, and tomado generated missiles will be established from he following equations:

$$
\begin{aligned}
& W^{\prime}=W_{*} \\
& W^{\prime}=W_{p} \\
& W^{\prime}=W_{m} \\
& W^{\prime}=W_{w}+0.5 W_{p} \\
& W^{\prime}=W_{w}+W_{m} \\
& W^{\prime}=W_{w}+0.5 W_{p}+W_{m}
\end{aligned}
$$

where:

$$
\begin{aligned}
& W^{\prime} \quad=\text { Total tornado load } \\
& W_{w} \quad=\text { Tomado wind load } \\
& W_{p} \quad=\text { Tomado differential pressure load } \\
& W_{m} \quad=\text { Tornado generated missila load }
\end{aligned}
$$


Attachment

Page 3 of 3

The above wind speed and pressure drop parameters are consistent with those values approved by the NRC for the Advanced Boiling Water Reactor Design for Tornado Intensity in Region III as defined in Section 2.0 of Reference 3. Based on the extensive studies which define site specific tomado hazards for the Hanford area, these wind speed and pressure drop parameters are conservative for the WNP-2 site. These studies are discussed in detail in the report attached to Reference 2.

In addition, the Supply System is proposing that the missiles to be conidered consist of the full spectrum of missiles contained in Reference 5, Section 3.5.1.4. For thc se missiles, the proposed velocities are based on the above wind speed and pressure drop parameters. These missile velocities were developed by the Supply System using a methodology that we feel is consistent with that used to develop the SRP missile velocities. The Supply S istem will formalize the calculations associated with the development of thest: missile velocities ffer NRC has concurred with the proposed revised tomado design criteria, tut prior to use in design work.

By implementing the proposed revisions, the tomado design criteria will conservatively reflect the tomado hazards at WNP-2 while maintaining the objective of providing an annual probability of exceedance of design loads of less than or equal to $1 \times 10^{-7}$. Thes revisions will result in more realistic wind velocities, differential pressure loads, missile velocities, and load combinations. The proposed revisions will bentefit the design of exterior structures and components that must consider postulated tornado effects. Significant benefit is expected during the implementation of future plant modifications where the revised tornado design criteria will facilitate construction. An example of this application is the Supply System's current effort to procure and install a dry cask spent fuel storage facility. 
WHC-SD-SNF-DB-010 REV 1

This page intentionally left blank.

A-8 
WHC-SD-SNF-DB-010 REV 1

APPENDIX B

REVISION OF TORNADO DESIGN CRITERIA FOR THE WASHINGTON PUBLIC POWER SUFPLY SYSTEM (WPPSS)

NUCLEAR PROJECT NO. 2 (WNP-2) 
WHC-SD-SNF-DB-010 REV 1

This page intentionally left blank. 
WHC-SD-SNF-DB-010 REV 1
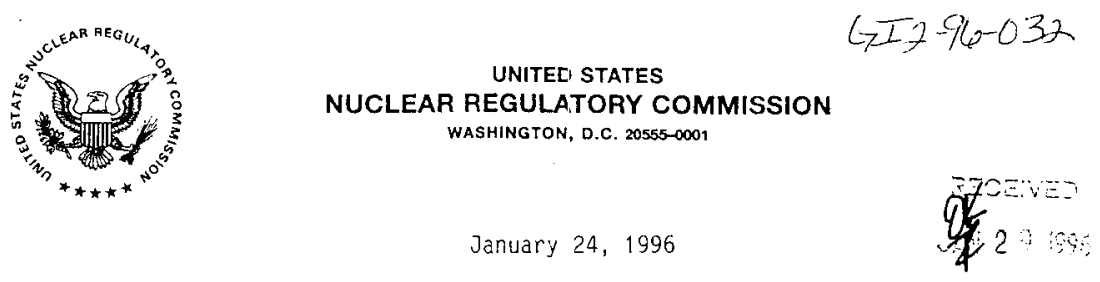

Mr. J. V. Parrish (Mail Drop 1023)

Vice President Nuciear Operations

3000 George Washington Way

Washington Public Power Supply System

P.0. Box 968

Richland, Washington 99352-0968

SUBJECT: REVISION OF TORNADO DESIGN CFITERIA FOR THE WASHINGTON PUBLIC

POWER SUPPLY SYSTEM (WPPSS) NUCLEAR PROJECT NO. 2 (WNP-2)

(TAC N0. M88626)

Dear Mr. Parrish:

By letter dated January 6, 1994, as mocified by letter dated 0ctober 10, 1995, you requested staff review and approval of a proposed revision to the tornado design criteria for WNP-2. Our review is documented in the enclosed safety evaluation. We have determined that ycur proposed changes to the design tornado wind speeds and missile spectrum are acceptable.

This completes our work on TAC No. M88E26. PTease contact me at 301-4I5-1352 if you have any questions.

Sincerely,

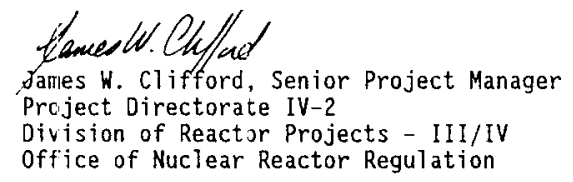

Docket No. 50-397

Enclosure: Safety Evaluation

cc w/enclosure:

See next page 
Cc w/encl:

Mr. G. 0. Smith

WNP-2 Plant General Manager

Washington Public Power Supply System

P. 0. 80x 968

Richland, Washington 99352-0968

Chief Counsel (Mai1 Drop 396)

Washington Public Power Supply System

P.0. Box 968

Richland, Washington 99352-0968

Mr. Frederick S. Adair, Chairman

Energy Facility site Evaluation Council

P. 0. Box 43172

01ympia, Washington 98504-3172

Mr. D. A. Swank (Mail Drop PE20)

WNP-2 Licensing Manager

Washington Pubic Power Supply System

P.O. Box 968

Richland, Washington 99352-0968

Mr. Paul R. Bemis (Mail Drop PE20)

Director, Regulatory and Industry Affairs

Washington Public Power Supply System

P.0. Box 968

Richland, Washington 99352

Regional Administrator, Region IV

U.S. Nuclear Regulatory Commission

Harris Tower \& Pavilion

611 Ryan Plaza Drive, Suite 400

Arlington, Texas 76011-8064

Chairman

Benton County Board of Commissioners

P.0. Box 69

Prosser, Washington 99350-0190

Mr. R. C. Barr, Senior Resident Inspector

U.S. Nuclear Regulatory Commission

P.0. Box 69

Richland, Washington 99352-0968

M. H. Philips, Jr., Esq.

Winston \& Strawn

$1400 \mathrm{~L}$ Street, N.W.

Washington, DC 20005-3502 
WHC-SD-SNF-DB-010 REV 1

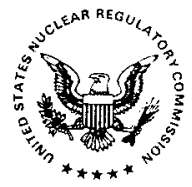

\author{
UNITED STATES
}

NUCLEAR REGULATORY COMMISSION

WASHINGTON, D.C. 20555-0001

SAFETY EVALUATION BY THE OFFICE OF NUCLEAR RI:ACTOR REGULATION

RELATED TO REVISED TCRNADO DESIGN CRITERIA

WASHINGTON PUBLIC FOWER SUPPLY SYSTEM

NUCLEAR PROJECT NO. 2

DOCKET NO. $50-397$

\title{
1.0 INTRODUCIIION
}

By letter dated January 6, 1994, the Washington Public Power Supply System (the Supply System or the licensee) recluested the staff's approval to revise the tornado design criteria for the WPFSS Nuclear Project No. 2, (WNP-2). By letter dated July 13, 1995, the staff requested additional justification for the licensee's proposed maximum composite wind speed of $192 \mathrm{mph}$. By letter dated October 10, 1995, the Supply System modified their proposed maximum composite wind speed to $200 \mathrm{mph}$ and provided supporting justification. The current licensing basis tornado design criteria for $W N P-2$ are wind speeds of $300 \mathrm{miles}$ per hour (mph) rotational and $60 \mathrm{mph}$ translational. The proposed change, as requested in the October 10, 1995 submittal, would revise the criteria to establish the total design basis tornado wind speed at $200 \mathrm{mph}$ (160 mph rotational and $40 \mathrm{mph}$ transiational). The request is based on the design basis tornado characteristics (for the tornado intensity region in which WNP-2 is located) accepted by the staff in NUREG-1503, "Final Safety Evaluation Report Related to the Certification of the Advanced Boiling Water Reactor Design," July 1994.

\subsection{EVALUATION}

The current licensing basis tornado design criteria for WNP-2 are based on a tornado Region I plant site as defined in Regulatory Guide (RG) 1.76, "Design Basis Tornaúo foi Nuclear fower Piants." These are excessive criteria for WNP-2 because it is located in a tornaclo Region III as defined in RG 1.76. The licensee's proposed tornado wind sfleed is also less than the wind speed identified in RG 1.76 for a design basis Region III tornado. This further reduction in tornado design criteria is consistent with the design basis characteristics accepted by the staff in NUREG-1503. Table 2-1 of NUREG-1503 establishes revised design basis tornaclo characteristics that are acceptable to the staff. The licensee's proposed revision is consistent with that table.

In NUREG-1503, the staff refers to SECY-93-087, "Policy, Technical, and Licensing Issues Pertaining to Evoluticnary and Advanced Light-Water Reactor (ALWR) Designs, " dated April 2, 1993, as a basis for revised tornado wind speeds. As described in SECY-93-087, the staff reevaluated the regulatory positions in RG 1.76 using the considerable quantity of tornado data which has become available since RG 1.76 was developed. This reevaluation is discussed 
in NUREG/CR-4661, "Tornado C1 imatology of the Contiguous United States," dated May 1986. Based on the updated tornado data and the analysis provided in NUREG/CR-4661, the staff concluded (in SECY-93-087) that it is acceptable to reduce the tornado design basis wind speeds to $322 \mathrm{ki}$ ometers per hour $(\mathrm{km} / \mathrm{hr})$ (200 mph) for states west of the Rocky Mountains and to $482 \mathrm{~km} / \mathrm{hr}$ (300 mph) for states east of the Rocky Mountains. The staff, therefore, concludes that the licensee's proposed reduction in design basis tornado wind speed to 200 mph is acceptable for WNP-2 which is located west of the Rocky Mountains. The licensee's proposed pressure drop and rate of pressure drop associated with the $200 \mathrm{mph}$ tornado are also acceptable because they are consistent with the design basis tornado characteristics found acceptable to the staff in Table 2-1 of NUREG-1503.

The licensee also proposed to revise the design basis tornado missile spectrum associated with the revised design basis tornado for WNP-2. The licensee calculated the impact velocities for the proposed tornado missile spectrum based on the reduced wind speed of $200 \mathrm{mph}$. The 1 icensee's proposal used Missile Spectrum II identified in Section 3.5.1.4 of the Standard Review Plan (SRP). Because the missile spectrum is consistent with Section 3.5.1.4 of the SRP, the staff concludes that it is acceptable.

It should aiso be recognized that the tornado design tasis requirements have been used in establishing structural requirements (minimum concrete wall thicknesses) for the protection of safety-related structures, systems, and components against effects not covered explicitly in review guidance such as regulatory guides and the Standard Review Plan. Specifically, some aviation (general aviation light aircraft) crashes, nearby explosions, and explosion debris or missiles have been reviewed and evaluated routinely by the staff by taking into account the existence of the tornado protection requirements. Therefore, for any new structures that are built using the revised tornado design criteria, the 1 icensee should perform an analys is under 10 CFR 50.59 to verify that the structures are adequate, based on minimum wall thickness, have walls thick enough to protect against other postulated site-specific hazards or loads that may have been previously subsumed within the tornado design basis.

\subsection{CONCIUSIOP!}

Based on the above evaluation, the staff concludes that the licensee's proposed revised criteria for the design basis tornado are in accordance with the guidelines of RG 1.76 regarding the missile spectrum and with the staff's revised design basis tornado characteristics set forth in NUREG-1503. The staff, therefore, concludes that the proposed changes are acceptable.

Principal Contributor: W. LeFave

Date: January 24, 1996 